\title{
SPECTROPHOTOMETRIC DETERMINATION OF TOTAL IRON IN RICE AND MAIZE SAMPLES
}

\author{
Armila Rajbhandari* and Tara Subedi** \\ *Central Department of Chemistry, Tribhuvan University, Kirtipur. \\ **Tri-Chandra Multiple Campus, Tribhuvan University, Kathmandu.
}

\begin{abstract}
A simple and sensitive spectrophotometric method was investigated for the determination of iron in rice and maize samples. The method is based on the formation of ferrous tris-o-phenanthroline complex by boiling with hydroxylamine hydrochloride and subsequent addition with 1,10 - phenanthroline at $\mathrm{p}^{\mathrm{H}} \sim 3 \pm 0.2$. The work presented here reports on optimization of phenanthroline method. The maximum absorbance was found to be at $510 \mathrm{~nm}$ wavelength. A calibration curve was found to be linear at the concentration range of $0.1 \mathrm{mg} / \mathrm{L}$ to $1 \mathrm{mg} / \mathrm{L}$. This method was successfully employed for the determination of iron in water, rice and maize samples.
\end{abstract}

Keywords: Iron content; Spectrophotometry; Water; Rice; Maize.

\section{INTRODUCTION}

Iron is widely distributed in natural water as well as in biological systems. It takes part in variety of biochemical processes like synthesis of hemoglobin, myoglobin and iron porphyrin enzymes. It is an absolute requirement for most forms of life, including human and most bacterial species. Though, it is one of the most essential micronutrients for human beings yet it is toxic when its concentration is higher than $0.3 \mathrm{mg} / \mathrm{L}$ in drinking water. The WHO limit of iron in drinking water is $0.3 \mathrm{mg} / \mathrm{L} \mathrm{[1]}$.

For the fulfillment of iron requirements, one can consume iron from different food resources. The recommended dietary allowances of iron is $11 \mathrm{mg}$ for 14-18 years old male and $15 \mathrm{mg}$ for females [2]. Its deficiency may cause disease like anemia, cheilosis, excretional dypsnoea, irritability, neurologic pain [3]. The cereals are one of the major diet used all over the world in order to fulfill iron requirement. In this study, we try to find out the iron content in rice and maize. Literatures revealed that there are several methods for the determination of iron [4-6]. Here, a simple, sensitive spectrophotometric method for the determination of iron content in rice and maize samples were investigated and is applied for the determination of iron level in water, rice and maize samples.

\section{EXPERIMENTAL}

\section{Materials}

All the reagents used were of AR grade and were used without any further purification. Stock Mohr's salt $\left[\mathrm{Fe}\left(\mathrm{NH}_{4}\right)_{2}\left(\mathrm{SO}_{4}\right)_{2} \cdot 6 \mathrm{H}_{2} \mathrm{O}\right]$ (AR grade) solution was prepared by dissolving $1.404 \mathrm{gm}$ in $1000 \mathrm{~mL}$ water. Calibration standard solutions were then prepared by taking appropriate volumes of stock iron solution. Hydroxylamine hydrochloride $\left(\mathrm{NH}_{2} \mathrm{OH} . \mathrm{HCl}\right)(1.5 \mathrm{M})$ solution was prepared by dissolving $10 \mathrm{gm}$ in 100 $\mathrm{mL}$ distilled water. Ammonium acetate buffer was prepared by taking $62.5 \mathrm{gm}$ of $\mathrm{AR}$ ammonium acetate $\left(\mathrm{NH}_{4} \mathrm{C}_{2} \mathrm{H}_{3} \mathrm{O}_{2}\right)$ in $40 \mathrm{~mL}$ distilled water and then 175 $\mathrm{mL}$ glacial acetic acid was added. Sodium acetate solution was prepared by weighing $25 \mathrm{gm}$ of AR sodium acetate $\left(\mathrm{NaC}_{2} \mathrm{H}_{3} \mathrm{O}_{2} .3 \mathrm{H}_{2} \mathrm{O}\right)$ and dissolved in $100 \mathrm{~mL}$ distilled water. Phenanthroline reagent was prepared in laboratory by dissolving 0.1 gm of 1-10 phenanthroline monohydrate $\left(\mathrm{C}_{12} \mathrm{H}_{8} \mathrm{~N}_{2} \cdot \mathrm{H}_{2} \mathrm{O}\right)$ in $100 \mathrm{~mL}$ distilled water and heating to $80^{\circ} \mathrm{C}$. The $0.1 \mathrm{gm}$ of hydroquinone is dissolved in $100 \mathrm{~mL}$ water to get hydroquinone solution.

Apparatus

WPA-S 104 Spectrophotometer was used in present investigation.

\section{Methods}

Principle of Phenanthroline Method

All the iron is converted into ferrous state by boiling with hydroxylamine hydrochloride. The reaction is as follows:

$4 \mathrm{Fe}^{+3}+2 \mathrm{NH}_{2} \mathrm{OH} \cdot \mathrm{HCl} \longrightarrow 4 \mathrm{Fe}^{+2}+\mathrm{N}_{2} \mathrm{O}+4 \mathrm{H}^{+}+\mathrm{H}_{2} \mathrm{O}$

The reduced iron chelates subsequently with 1,10

Author for Correspondence: Armila Rajbhandari, Central Department of Chemistry, Tribhuvan University, Kirtipur. E-mail: armila3@yahoo.com. 
- phenanthroline at $\mathrm{p}^{\mathrm{H}} 3.2$ to 3.3 and forms an orange - red colour complex. The intensity of the colour is proportional to the amount of iron present in sample solution and follows Beer's law and therefore, can be determined colorimetrically.

Determination of $\lambda_{\max }$

The $\lambda_{\text {max }}$ was determined by measuring absorbance at various wavelengths from 400 to $600 \mathrm{~nm}$.

\section{Preparation of Calibration Curve}

The absorbance of each 1 to $10 \mathrm{mg} / \mathrm{L}$ standard solutions were measured. A calibration curve was then obtained by plotting the absorbance as a function of concentration of iron in $\mathrm{mg} / \mathrm{L}$.

\section{Study area and sample collection}

All the samples (water, rice and maize) under study were taken from Kathmandu valley and random sampling technique was adopted.

All the water samples were collected from deep wells of Kathmandu valley. The sampling sites chosen in this study were Tinthana, Baneswor, Sanepa, Banasthali, Bafal, Kirtipur, Kalimati, Koteswor, Satungal, Lainchor, Samakhusi, Thankot, Kalanki, Baluwatar and Balkhu.

The five rice samples were collected from five different places of Kathmandu valley. The local name of this rice is Mansuli. The colour of rice grain is white having small grain size. Similarly, five different maize species were also locally grown in Kathmandu Valley and were collected for the study. The Kalanki, Kirtipur, Banasthali, Bhaktapur and Balkhu were the sampling sites chosen for the study of rice and maize.

\section{Procedure for the determination of iron in ground water}

The $50 \mathrm{ml}$ of water sample was taken in $125 \mathrm{~mL}$ Erlenmeyer flask. The $2 \mathrm{~mL}$ of concentrated $\mathrm{HCl}, 1 \mathrm{~mL}$ of hydroxylamine solution were added. Then, the mixture solution was heated to boiling. To ensure the complete dissolution of all the iron, boiling was continued until the sample volume was reduced approximately to 20 $\mathrm{mL}$.

After cooling to room temperature, the sample was transferred to $100 \mathrm{~mL}$ volumetric flask. In this solution, $10 \mathrm{~mL}$ of ammonium acetate buffer and $2 \mathrm{~mL}$ of the phenanthroline solution were added. The sample solution was then diluted to $100 \mathrm{~mL}$ with distilled water and mixed thoroughly. It was then allowed to stand for 10 minutes for maximum colour development. After the colour development, the absorbance was measured in spectrophotometer at $510 \mathrm{~nm}$ wavelength.

Procedure for the determination of in rice and maize samples
The samples of rice were collected in plastic cups. Rice samples were grinded into fine powder using pestle. 1 gm of crushed rice was weighed out in beaker. $50 \mathrm{~mL}$ of $1 \mathrm{M} \mathrm{HCl}$ was added to it and stirred well. Beakers were then covered with watch glasses and placed on hot plate and heated for 30 minutes at $80^{\circ} \mathrm{C}$. After 30 minutes, solutions were allowed to cool to room temperature and filtered. The total volume of the rice solution was measured. Then rice solution was transferred into 150 $\mathrm{mL}$ beakers. The $\mathrm{p}^{\mathrm{H}}$ was maintained to 3.3 by adding appropriate volume of potassium citrate solution. Thus, prepared cereal solution was transferred to $100 \mathrm{~mL}$ volumetric flask. Then, $2 \mathrm{~mL}$ of hydroquinone solution; $5 \mathrm{~mL}$ of $0.25 \%$ ortho-phenanthroline solution were added. Finally, the volume was made upto the mark. The cereal solution was allowed to stand for 15 minutes for maximum colour development. The absorbance was then measured at $510 \mathrm{~nm}$ wavelength. The sample of maize was also extracted in a similar procedure applied for rice samples.

\section{RESULT}

Determination of $\lambda_{\text {max for the estimation of iron }}$

As can be seen in Fig. 1, $\lambda_{\text {max }}$ was obtained at $510 \mathrm{~nm}$ of wavelength. The $510 \mathrm{~nm}$ of wavelength was then chosen for entire work.

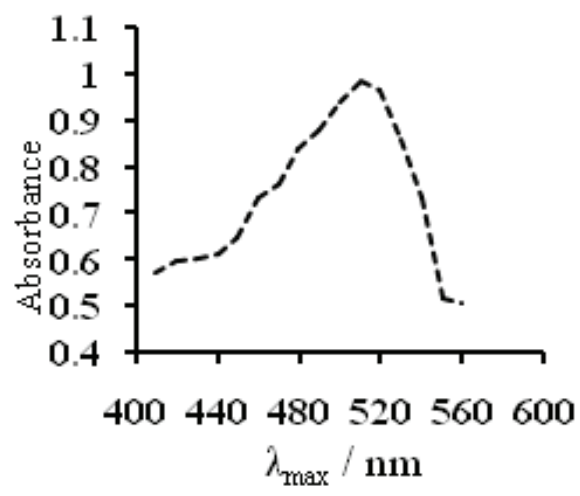

Fig.1: Determination of $\lambda_{\text {max }}$

Calibration curve for the determination of iron

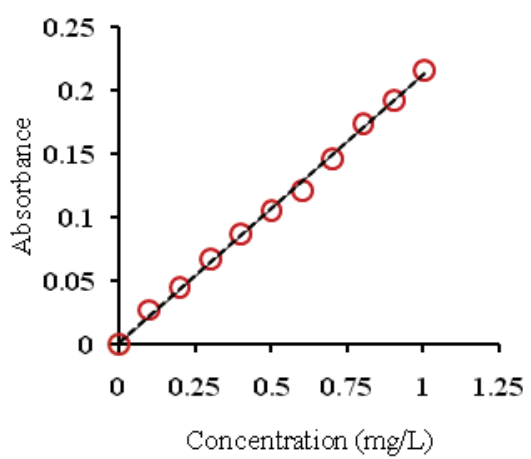

Fig. 2: Calibration curve for the determination of iron 
Absorbance of series of standard iron solutions (0.1, $0.2,0.3 \quad 0.4 \ldots \ldots .1 .0 \mathrm{mg} / \mathrm{L})$ were measured at 510 $\mathrm{nm}$ wavelength and calibration curve was obtained by plotting absorbance as a function of concentration of iron solution $(\mathrm{mg} / \mathrm{L})$. Fig. 2 shows the calibration curve for the determination of iron. In the plot, the points are the experimental values and the line is the line of best fit computed from the regression analysis.

\section{Determination of total iron in water samples}

The amount of iron in different water samples were calculated with the help of calibration curve. All the samples were found to contain higher iron level $>1$ $\mathrm{mg} / \mathrm{L}$. Fig. 3 shows the iron content in different water samples. It clearly shows that level of iron in water is higher than WHO limit [1]. The samples from Kirtipur, Kalimati, Koteswor, Satungal, Lainchor and Samakhusi showed extremely high iron content.

\section{Determination of total iron in different samples of rice}

The total iron contents of rice samples collected from

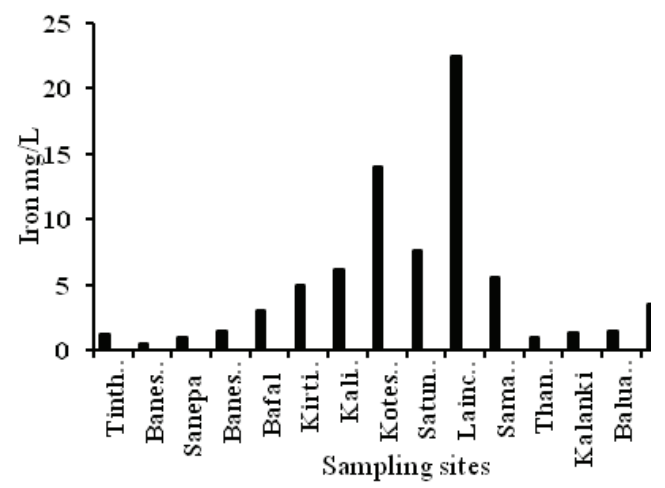

Fig. 3: The bar diagram showing the level of iron in different samples of water.

five different sampling sites were analyzed. All the data obtained from rice samples showed the iron level ranges from 2.0 to $3.5 \mathrm{mg}$ per $100 \mathrm{gm}$ of rice which is little lower than suggested by USDA (2006) [7].

The total iron content $(2.5 \pm 0.5 \mathrm{mg}$ per $100 \mathrm{gm})$ of rice sample of Kathmandu Valley was compared with the rice samples of Australia (2.6 mg per $100 \mathrm{gm}$ ), Korea (0.7 mg per 100 gm), India (2.2 mg per 100 gm), Vietnam (1.2 mg per $100 \mathrm{gm})$ and Philippines (1.2 mg per $100 \mathrm{gm}$ ) [8]. These values were expressed in bar diagram and is shown in Fig. 4.

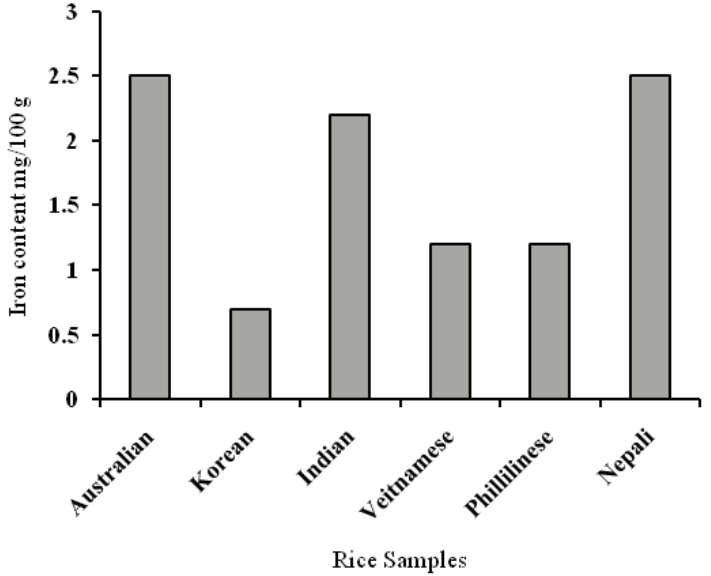

Fig.4: The figure showing the level of iron in Nepali rice sample and the value is compared with rice samples of 5 different countries.

In the figure, the level of iron in Nepali rice sample and the value is compared with rice samples of 5 different countries namely, Australia, Korea, India, Vietnam, Philippines. It is obvious that Nepali rice had similar level of iron as in Australian and Indian rice.

\section{Determination of Total Iron Content in Maize Samples}

The total iron contents of maize samples collected from 5 different sampling sites were evaluated. The values indicated that almost all the maize samples contain a little higher iron level ranging from 1.7 to $2.2 \mathrm{mg}$ per $100 \mathrm{gm}$ than as indicated by the USDA (2006) [7].

The total iron content $(2.0 \pm 0.2 \mathrm{mg}$ per $100 \mathrm{gm})$ of maize sample of Kathmandu Valley was compared with the study done in maize samples of Africa $(1.8 \mathrm{mg}$ per $100 \mathrm{gm}$ ) [11] and America (2.2 mg per $100 \mathrm{gm}$ ) [12]. These values were expressed in bar diagram as shown in Fig. 5.

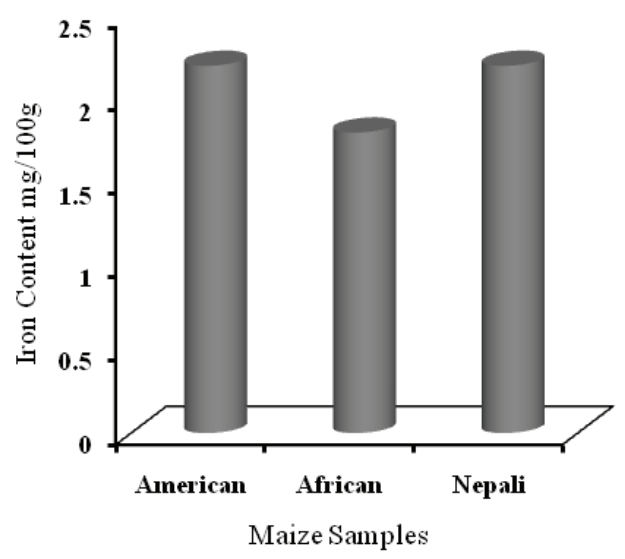

Fig. 5: The figure showing the level of iron in Nepali maize sample and is compared with American and African maize samples.

As can be seen in the Fig. 5 iron content of Nepali maize with those of foreign maizes are almost similar. 


\section{DISCUSSION}

The present study revealed that the level of iron in ground water of different places of Kathmandu was found to be ranged from 0.5 to $22.5 \mathrm{mg} / \mathrm{L}$. Most of the samples have very high concentration which is quite higher than WHO limit of $0.3 \mathrm{mg} / \mathrm{L}$. Results revealed on rice samples of Kathmandu valley showed that the total iron content were ranged from 2.0 to $3.5 \mathrm{mg}$ per $100 \mathrm{gm}$ of rice sample. These results are quite comparable with USDA Nutrient Database 2006 ie. $4.31 \mathrm{mg}$ iron per 100 gm of rice [7]. Trinidap et. al. [8] have reported level of iron in Indian rice samples in which they found $5 \mathrm{mg}$ iron per 100 gm of rice. Similarly, Jiangfen L. (2007) [9] has reported iron levels of 56 rice varieties from China which ranged from 0.9 to $4.5 \mathrm{mg}$ per $100 \mathrm{gm}$ of rice samples. Whereas, in Australian, Korean, Vietnamese and Philippines rice samples they found $2.6 \mathrm{mg}, 0.7 \mathrm{mg}$, $2.2 \mathrm{mg}$ and $1.2 \mathrm{mg}$ per $100 \mathrm{gm}$ of rice samples [10]. The rice samples of Nepal showed the similar content of iron as in Australian samples.

The maize samples of Kathmandu valley contained $1.7 \mathrm{mg}$ to $2.0 \mathrm{mg}$ per $100 \mathrm{gm}$ of maize which is quite similar with the iron content found by Oikeh et. al. [12] in 20 tropical maize varieties grown in west Africa and America which are higher than USDA Nutrient Database (2006) value of $0.52 \mathrm{mg}$ per $100 \mathrm{gm}$ of maize [7].

\section{CONCLUSION}

1-10 Phenanthroline spectrophotometric method is simple, reliable and rapid method for the determination of iron from solution. It can be used for the determination of iron content in water sample as well as rice and maize samples.

\section{ACKNOWLEDGEMENT}

We would like to acknowledge Trichandra Campus, Tribhuvan University to provide laboratory facilities to carry out the research work.

\section{REFERENCES}

[1] www. WHO.int / water sanitation health / dwq / chemicals / iron. pdf.International Agency for Research.

[2] Florence, T.M. and Bartley, G.E. 1985. Rev. Anal.Chem. 9:259.

[3] Human Metabolism, Wikipedia, http : // www. en. Wikipedia. org / Wiki / iron.

[4] Krekler, S., Frenzel, W. and Schulze, G. 1994. Anal. Chim. Acta. 296:115.

[5] Minzdraw, R.F. 1996. Practical guidelines 4.1.064, Moscow.

[6] Golovina, A. N. and Levshin, L. V. 1978. Chemical Luminiscent Analysis of Neorganical Substances, Moscow, Khimiya.

[7] American Dietic Association's complete food and guides $2^{\text {nd }}$ edition. 2002. USAD National Nutrient database.

[8] Trinidad, P., Aida, C., Mallillin, Rosario, S., Sagum, Dave, P., Briones, Rosaria R., Encabo and Bienvenido O. 2006. Iron and zinc availability from brown rice/brown rice-based meal and milled rice/milled rice-based meal of the same variety. Research and Development work FNRI Dost.
[9] Jianfen, L., Iron, Zinc. and Phytic Acid in Rice from China, Wet and Dry Processing towards Improved Mineral Bioavailability.

[10] Oikeh, S. O., Menkir, A., Maziya-Dixon, B., Welch, R. and Glahn ,R. P. 2003. U.S. Plant, Soil and Nutrition Laboratory, Agricultural Research Service, U.S. Department of Agriculture, Cornell University, Tower Road,Ithaca, New York, 14853, USA.

[11] Salvador, J. and Lopez, G. 2003. Iron availability from corn tortilla \& cooked beans (Phaseous Vulgaris) ; A study on the effect of Fiber.

[12] Oikeh, S. O., Menkir, A., Maziya, D. B., Welch, R. and Glahn, R. P. 2003. J. Agric. Food Chem. 51:3688-94. 